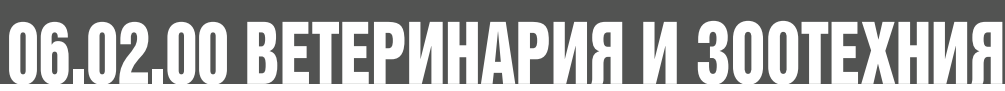

УДК 636.598

DOI 10.18286/1816-4501-2018-3-110-116

\section{ФАЗОВОЕ КОРМЛЕНИЕ В ГУСЕВОДСТВЕ}

Галина Чулпан Рифовна, кандидат сельскохозяйственных наук, старший научный сотрудник отдела интенсивных технологий в животноводстве

Башкирский научно-исследовательский институт сельского хозяйства - обособленное структурное подразделение Федерального государственного бюджетного научного учреждения Уфимского Федерального исследовательского центра Российской академии наук

450059, Республика Башкортостан, г. Уфра, ул. Рихарда Зорге, 19.

тел.: +7-937-16-44-516;

e-mail: chulpan-galina@mail.ru

Ключевые слова: гуси, кормление, обменная энергия, протеин, продуктивность, гематологические показатели, экономическая эффрективность.

Целью исследований явилось повышение продуктивных качеств гусей родительского стада путем фазового кормления в зависимости от физиологического состояния и уровня продуктивности. Исследования проводились на гусях родительского стада итальянской породы в гусеводческом хозяйстве ООО «Башкирская птица» Благоварского района Республики Башкортостан. Были сформированы контрольная и три опытные группы по 20 голов в каждой. Гусей опытных групп кормили пофазно в зависимости от уровня продуктивности. В рационе гусей опытной-1 группы содержание обменной энергии (ОЭ) в первой фразе продуктивности составило 260 ккал, во второй - 265, в третьей - 270 ккал с содержанием сырого протеина (СП) - 16,0; 17,0 и 17,5\% соответственно. В рационе опытной-2 группы содержание ОЭ составило 270; 275; 270 ккал, а СП - 16,5; 17,0 и 16,5\% соответственно; в опытной-3 группе - 270; 275 и 270 ккал ОЭ и 17,0; 17,5 и 17,0\% СП соответственно. Гуси контрольной группы получали основной рацион согласно рекомендациям ВНИТИП. По результатам исследований выявлено, что живая масса гусей опытной-3 группы к концу продуктивного периода была выше в среднем на 4,0\%, яйценоскость - на 10,3\%, масса яйца - на 1,0\% по сравнению с контролем. В крови гусей опытной-3 группы выявлено большее содержание гемоглобина на 6,9\%, эритроцитов - на 3,83\%, лейкоцитов - на 6,5\% по сравнению с контролем. Процент вывода кондиционных гусят в опытной-3 группе повысился на 22,4\%, чем в контроле, а уровень рентабельности возрос на 10,6\%. Таким образом, в продуктивный период гусей родительского стада челесообразно производить фазовое кормление с содержанием в рационе ОЭ в первой фазе 270 ккал, во второй - 275, в третьей - 270 ккал и СП на уровне 17,$0 ; 17,5$ и 17,0\% соответственно.

\section{Введение}

В условиях современной рыночной экономики для повышения рентабельности и конкурентоспособности отрасли российского птицеводства, инвестиционной привлекательности птицеводческих предприятий и снижения всех затрат требуется внедрение новых научно обоснованных технологических приемов производства, способствующих экономии затрат кормов и других ресурсов, а также увеличению производства высококачественного экологически безопасного птичьего мяса, расширения ассортимента птицеводческой продукции для удовлетворения потребностей различных слоев населения [1 - 4].

Одним из важнейших факторов, влияющих на эффективность птицеводства, является сбалансированное, экологически безопасное, полноценное кормление, удовлетворяющее потребностям организма в питательных веществах с учетом физиологического состояния и уровня продуктивности [5 - 10]. С данной точки зрения 
наиболее перспективным в птицеводстве является фазовое кормление, заключающееся в оптимизации содержания обменной энергии (ОЭ) и сырого протеина (СП) в рационе в зависимости от возраста и уровня продуктивности птицы [11].

В связи с этим, целью наших исследований явилось повышение продуктивных качеств гусей родительского стада путем фазового кормления в зависимости от физиологического состояния и уровня продуктивности. Для достижения данной цели были поставлены следующие задачи: выявить оптимальное содержание обменной энергии и сырого протеина в рационе гусей родительского стада в период яйцекладки с учетом физиологического состояния и уровня продуктивности; изучить продуктивные качества и гематологические показатели гусей родительского стада при фазовом кормлении; рассчитать экономическую эффективность содержания гусей.

\section{Объекты и методы исследований}

Исследования проводились на гусях родительского стада итальянской породы в гусеводческом хозяйстве ООО «Башкирская птица» Благоварского района Республики Башкортостан.

Для выявления оптимальных объемов содержания обменной энергии и сырого протеина в рационах гусей родительского стада в период яйцекладки были сформированы одна контрольная и три опытные группы по 20 голов в каждой. В продуктивный период гусей родительского стада опытных групп кормление производили пофазно в зависимости от уровня продуктивности: первая фаза - от начала до пика яйцекладки; вторая фаза - от пика яйцекладки до спада интенсивности яйценоскости до 30\%; третья фаза - с периода снижения яйценоскости до завершения яйцекладки. В рационе гусей опытной-1 группы содержание обменной энергии в первой фазе продуктивности составило 260 ккал, во второй - 265 и в третьей - 270 ккал с содержанием сырого протеина - 16,0; 17,0 и 17,5\% соответственно. В рационе опытной-2 группы содержание обменной энергии по фазам продуктивности составило 270; 275; 270 ккал, а сырого протеина - 16,5; 17,0 и 16,5\% соответственно; в опытной-3 группе - 270; 275 и 270 ккал ОЭ и 17,0; 17,5 и 17,0 \% сырого протеина соответственно. Гуси контрольной группы получали основной рацион с содержанием в 100 г комбикорма 260 ккал обменной энергии и $16,0 \%$ сырого протеина, согласно методическим рекомендациям ВНИТИП. Технологические параметры содержания гусей были идентичными во всех группах. Продолжительность исследований составила 150 дней. Статистическую обработку результатов исследований выполнили методом вариационной статистики. Оценку достоверности различий проводили по t-критерию Стьюдента.

\section{Результаты исследований}

Живая масса гусей является одним из важных показателей, учитываемых в селекционной работе. Она зависит от породной принадлежности, пола птицы, технологических факторов и т.д.

Динамика живой массы гусей с учетом пола по месяцам продуктивности представлена в табл. 1.

Таблица 1

Динамика живой массы гусей в продуктивный период, r (X \pm Sx)

\begin{tabular}{|c|c|c|c|c|}
\hline \multirow{2}{*}{$\begin{array}{c}\text { Месяц } \\
\text { яйцекладки }\end{array}$} & \multicolumn{4}{|c|}{ Группа } \\
\hline & контрольная & опытная-1 & опытная-2 & опытная-3 \\
\hline \multicolumn{5}{|c|}{ самцы } \\
\hline Февраль & $6271,7 \pm 61,8$ & $6283,5 \pm 51,7$ & $6274,1 \pm 54,2$ & $6285,4 \pm 60,9$ \\
\hline Март & $6163,2 \pm 66,7$ & $6170,4 \pm 63,9$ & $6186,6 \pm 64,6$ & $6227,9 \pm 67,2$ \\
\hline Апрель & $6009,4 \pm 71,9$ & $6021,3 \pm 73,4$ & $6058,5 \pm 75,1$ & $6082,6 \pm 72,7$ \\
\hline Май & $5893,8 \pm 51,1$ & $5932,5 \pm 55,3$ & $5967,3 \pm 57,8$ & $6036,7 \pm 50,1^{*}$ \\
\hline Июнь & $5803,2 \pm 42,6$ & $5861,4 \pm 47,9$ & $5934,7 \pm 41,5^{*}$ & $6092,6 \pm 48,3^{* *}$ \\
\hline \multicolumn{5}{|c|}{ самки } \\
\hline Февраль & $5186,1 \pm 58,5$ & $5183,4 \pm 55,3$ & $5178,3 \pm 57,9$ & $5191,7 \pm 59,4$ \\
\hline Март & $5027,4 \pm 60,7$ & $5041,7 \pm 54,6$ & $5051,9 \pm 58,1$ & $5089,3 \pm 60,2$ \\
\hline Апрель & $4909,6 \pm 58,9$ & $4939,2 \pm 49,4$ & $4965,7 \pm 50,5$ & $4991,1 \pm 55,7$ \\
\hline Май & $4784,4 \pm 40,4$ & $4835,7 \pm 41,3$ & $4859,4 \pm 43,9$ & $4886,9 \pm 42,6$ \\
\hline Июнь & $4827,2 \pm 41,8$ & $4863,8 \pm 42,2$ & $4915,5 \pm 38,7$ & $4967,7 \pm 41,4^{*}$ \\
\hline
\end{tabular}




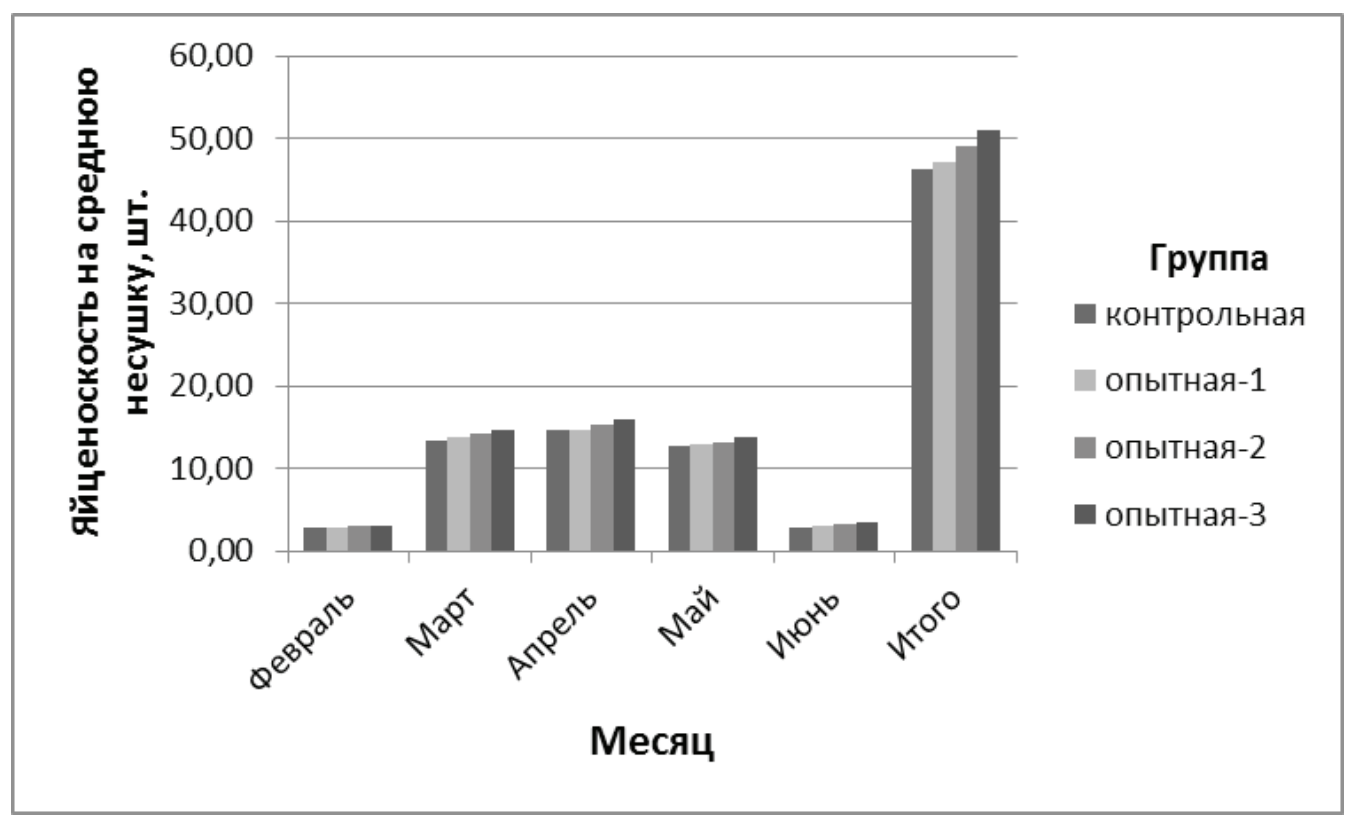

Рис. 1 - Яйценоскость гусынь на среднюю несушку, шт.

Таблица 2

Масса яиц, $г(X \pm S x)$

\begin{tabular}{|l|c|c|c|c|}
\hline \multirow{2}{*}{ Месяц яйцекладки } & \multicolumn{4}{|c|}{ Группа } \\
\cline { 2 - 5 } & контрольная & опытная-1 & опытная-2 & опытная-3 \\
\hline Февраль & $163,83 \pm 2,34$ & $164,17 \pm 2,34$ & $164,93 \pm 2,26$ & $165,31 \pm 2,29$ \\
\hline Март & $161,92 \pm 2,18$ & $162,32 \pm 2,17$ & $162,68 \pm 2,07$ & $163,14 \pm 2,23$ \\
\hline Апрель & $158,77 \pm 2,17$ & $159,38 \pm 2,58$ & $159,91 \pm 2,27$ & $160,27 \pm 2,74$ \\
\hline Май & $155,86 \pm 2,08$ & $156,18 \pm 2,32$ & $156,73 \pm 2,19$ & $157,34 \pm 2,37$ \\
\hline Июнь & $152,89 \pm 2,36$ & $153,41 \pm 2,54$ & $153,86 \pm 2,40$ & $155,09 \pm 2,68$ \\
\hline Среднее & $158,65 \pm 2,47$ & $159,09 \pm 2,36$ & $159,62 \pm 2,54$ & $160,23 \pm 2,65$ \\
\hline
\end{tabular}

Анализируя полученные данные, следует отметить, что с продолжительностью яйцекладки у самок всех групп живая масса к концу продуктивного периода постепенно снижалась. Так, живая масса гусынь контрольной группы за весь цикл яйцекладки снизилась на 7,4 \%, опытной-1 группы - на 6,6 \%, опытной-2 - на 5,3 \%. При этом наименьшее снижение живой массы было выявлено у гусынь опытной-3 группы, составив 4,5 \%, что на 2,9 \% было ниже по сравнению с контрольной. Аналогичная тенденция была выявлена и у гусаков: живая масса самцов опытной-3 группы была наибольшей в течение всего продуктивного периода и в июне месяце составила 6092,6 г, что на 5,0 \% (p<0,01); 3,9 и 2,3 \% было выше по сравнению с контрольной опытной-1 и опытной-2 группами соответственно.

Показатели яйценоскости гусынь на среднюю несушку по месяцам продуктивности представлены на рис. 1.

Как видно из рисунка 1, наиболее высокая яйценоскость была выявлена при фазовом кормлении гусей, а особенно в опытной-3 группе, где в рационе содержание обменной энергии и сырого протеина составляло: в первой фазе продуктивности - 270 ккал и $17 \%$, во второй фазе - 275 ккал и 17,5 \%, в третьей фазе - 270 ккал и 17 \% соответственно. За 5 месяцев продуктивности яйценоскость гусей в данной группе составила 50,97 яйца на среднюю несушку, что на 10,3 \% (p<0,01) было выше по сравнению с контрольной и на 4,1-8,0 \% по сравнению с другими опытными группами. Пик яйценоскости во всех испытуемых группах при этом пришелся на апрель месяц, где он составил у гусынь контрольной группы 14,57 шт., опытной-1 - 14,72 шт., опытной-2 - 15,38 шт. и опытной-3 - 15,87 шт. в расчете на среднюю несушку.

Результаты взвешивания яиц по месяцам яйцекладки представлены в табл. 2.

Исходя из полученных данных, следует отметить, что наиболее высокая масса яйца во всех группах была выявлена в феврале-марте , т.е. в начале яйцекладки, и колебалась в пределах 161,92-165,31 г, а с продолжительностью яйценоскости наблюдалось постепенное ее сни- 
Таблица 3

Морфобиохимический состав крови гусынь на пике яйцекладки $(\mathrm{X} \pm \mathrm{Sx})$

\begin{tabular}{|c|c|c|c|c|}
\hline \multirow{2}{*}{ Показатель } & \multicolumn{4}{|c|}{ Группа } \\
\hline & контрольная & опытная-1 & опытная-2 & опытная-3 \\
\hline Эритроциты, х 10 12/л & $2,35 \pm 0,21$ & $2,40 \pm 0,20$ & $2,42 \pm 0,24$ & $2,44 \pm 0,16$ \\
\hline Гемоглобин, г/л & $123,08 \pm 2,0$ & $127,52 \pm 2,18$ & $129,71 \pm 2,11^{*}$ & $131,6 \pm 2,03 * *$ \\
\hline Цветной показатель & $1,57 \pm 0,11$ & $1,59 \pm 0,14$ & $1,61 \pm 0,08$ & $1,62 \pm 0,10$ \\
\hline Лейкоциты, × 109 /л & $22,43 \pm 0,55$ & $22,93 \pm 0,71$ & $23,37 \pm 0,64$ & $23,88 \pm 0,43^{*}$ \\
\hline Щелочной резерв, мг\% & $661,27 \pm 6,68$ & $674,38 \pm 6,97$ & $680,82 \pm 6,72^{*}$ & $687,22 \pm 6,49 *$ \\
\hline Общий белок, г/л & $58,75 \pm 1,75$ & $58,32 \pm 1,82$ & $58,04 \pm 1,39$ & $57,91 \pm 1,57$ \\
\hline Общий азот, мг\% & $997,45 \pm 9,33$ & $994,06 \pm 8,94$ & $992,75 \pm 9,46$ & $990,93 \pm 9,14$ \\
\hline Остаточный азот, мг\% & $22,72 \pm 1,17$ & $22,51 \pm 1,22$ & $22,39 \pm 1,19$ & $22,24 \pm 1,23$ \\
\hline Кальций, ммоль/л & $5,63 \pm 0,86$ & $5,47 \pm 0,69$ & $5,24 \pm 0,75$ & $5,08 \pm 0,72$ \\
\hline Неорганический фосфор, ммоль/л & $1,15 \pm 0,09$ & $1,11 \pm 0,07$ & $1,08 \pm 0,10$ & $1,06 \pm 0,08$ \\
\hline
\end{tabular}

жение в среднем на 3,3 \%. В целом за исследуемый период наиболее крупные яйца были получены в опытной-3 группе, где средняя масса яйца составила 160,23 г и превосходила показатели контрольной, опытной-1 и опытной-2 групп на 1,0; 0,7 и 0,4 \% соответственно.

Как известно, гуси характеризуются густым перьевым покровом, плотно прилегающим к туловищу. При этом, наиболее высоко ценится гусиное пухо-перовое сырье, полученное путем проведения прижизненной ощипки. Такое сырье обычно состоит из зрелых, упругих, гибких и прочных перьев, имеющих низкий удельный вес. Пухо-перовое сырье, полученное методом прижизненной ощипки, по своему качеству отличается от сырья, полученного после убоя птицы. Оно содержит меньшее количество жира (ниже 1 \%), по сравнению с сырьем (4 \%), снятым с тушек гусей при промышленном убое [2]. Следует также отметить, что при начавшейся естественной линьке процесс снятия пера и пуха у гусей не оказывает влияния на их продуктивность, является безвредной и безболезненной технологической операцией.

По результатам наших исследований выявлено, что наибольшее количество перо-пухового сырья было получено от гусей опытной-3 группы и составило 95,32 г, что на 1,6 \%; 1,3 и 1,1 \% больше по сравнению с гусями контрольной, опытных-1 и -2 групп соответственно. Высокая массовая доля пуха была выявлена также у гусей опытной-3 группы (28,62\%), тогда как у гусей контрольной группы данный показатель составил всего 28,01 \%, т.е. был ниже на 0,6 \%.

Кровь вместе с лимфой и тканевой жидкостью образуют внутреннюю среду организма. Она образуется жидкой соединительной тканью, состоит из плазмы и форменных элементов. Благо- даря своим свойствам кровь выполняет дыхательную функцию, разносит по организму питательные вещества и защищает его от патогенов. Она также очищает клетки от продуктов метаболизма, шлаков и вредных веществ. По химическому составу крови можно выявить патологические изменения, происходящие в организме, поэтому изучение гематологических показателей имеет важное значение [12].

С целью изучения морфобиохимического состава крови гусей в период продуктивности мы проводили взятие крови из крыловой вены птицы в утреннее время за 1 час до их кормления.

Результаты исследований (табл. 3) показали, что морфологический состав крови гусей во всех группах находился в пределах физиологической нормы, однако были выявлены межгрупповые различия.

Содержание эритроцитов в крови гусей опытной-3 группы было наибольшим, составив $2,44 \times 10^{12} / л$, что превосходило контрольную, опытные-1 и -2 группы на 3,83; 1,67 и 0,83 \% соответственно.

По содержанию гемоглобина в эритроцитах прослеживалась аналогичная тенденция. Так, содержание гемоглобина у гусей опытной-3 группы составило в среднем 131,6 г/л и было больше, чем в контроле на 6,9 \% при достоверности различий р<0,01. В опытных - 1 и - 2 группах данный показатель был также больше по сравнению с контролем, где разница составила 3,6 и 5,4 \% в пользу опытных, однако они были меньше, чем в опытной-3 группе на 3,2 и 1,5 \% соответственно.

Цветной показатель крови дает представление об уровне содержания гемоглобина в отдельных эритроцитах [12]. Данный показатель 
нами рассчитывался отношением величины гемоглобина к числу эритроцитов и было выявлено, что в опытных группах он был наибольшим и колебался в пределах 1,59-1,62, что выше по сравнению с контролем на 1,3-3,2 \%. При этом наилучшими показателями отличались гуси опытной-3 группы, где цветной показатель составил 1,62 и превосходил другие группы на 0,63,2\%.

Лейкоциты играют важную роль в защите организма от неблагоприятных факторов внешней среды. Они могут захватывать и переваривать бактерии и другие инородные тела, попадающие в организм. Главными функциями лейкоцитов являются фагоцитоз, продуцирование антител, удаление белковых токсинов из организма. Они способны проникать сквозь стенки капилляров в межтканевое пространство [12].

Количество лейкоцитов в крови гусей опытных групп было больше по сравнению с контрольной. При этом наибольшее содержание лейкоцитов было выявлено в опытной-3 группе, что составило 23,85 x 109 /л и превосходило показатели контрольной, опытной-1 и опытной-2 групп на 6,5 \% (p<0,05); 4,1 и 2,2 \% соответственно. Данное явление можно объяснить тем, что количество лейкоцитов в крови значительно увеличивается при более интенсивном обмене веществ, связанном с повышением продуктивности птицы. Так, в данном продуктивном периоде яйценоскость гусей опытной-3 группы в расчете на среднюю несушку была наибольшей и превосходила контрольную, опытную-1 и опытную-2 группы на 8,9; 7,8 и 3,2 \% соответственно.

Кровь в норме имеет постоянную слабощелочную реакцию, что является необходимым условием для сохранения постоянства внутренней среды организма. Соотношение между кислотными и щелочными эквивалентами называется кислотно-щелочным равновесием или резервной щелочностью крови [12].

По результатам наших исследований выявлено, что щелочной резерв крови гусей имел определенные различия по группам. Так, в контрольной группе данный показатель составил 661,27 мг \% и был меньше, чем в опытной-1 группе на 2,0 \%. Разница между контрольной и опытными-2 и -3 группами была больше, составив 2,9 и 3,9 \% в пользу опытных при уровне достоверности $p<0,05$.

Содержание общего белка в сыворотке крови гусей опытных групп было ниже, чем в контроле. Так, разница по данному показателю между контрольной и опытными-1, -2 и -3 группами составила 0,73; 1,22 и 1,45 \% в поль- зу контрольной группы, соответственно, однако разница была недостоверной. По содержанию общего азота прослеживалась аналогичная тенденция: относительно большее количество было выявлено в сыворотке крови гусей контрольной группы, где оно составило 997,45 мг \%, и было выше, чем в опытных, на 0,34-0,65 \%. Относительно меньшее содержание общего белка и азота в сыворотке крови гусей опытных групп в сравнении с контролем, на наш взгляд, связано с более высокой продуктивностью и интенсивностью процессов белкового обмена в тканях организма.

Содержание остаточного азота в опытных группах колебалось в пределах 22,24-22,51 мг \%, а в контрольной - 22,72 мг \%. При этом в опытной-3 группе оно было наименьшим и составило 22,24 мг \%, что было ниже, по сравнению с контролем, на 2,1\%, а по сравнению с другими опытными группами - на 0,7-1,2\%. Возможно, это указывает на меньшее накопление продуктов распада в организме птицы 3-опытной группы по сравнению с другими группами.

Примерно 5-30\% кальция сыворотки крови входит в состав прочных биокомплексов. Общее количество кальция в крови изменяется в среднем на 10-20\%. Фосфор имеет большое значение для нормального усвоения кальция и формирования желтка яиц. Он входит в состав нуклеопротеидов, фосфоропротеидов, а также встречается в организме в форме неорганических фосфорнокислых солей. При недостатке фосфора у гусынь снижается яйценоскость, ухудшается качество скорлупы яиц и выводимость молодняка [12].

Содержание минеральных компонентов в сыворотке крови гусей на пике продуктивности по группам достоверно не отличалось и варьировалось: кальция от 5,08-5,47 ммоль/л в опытных до 5,63 - в контрольной; неорганического фосфора - от 1,06-1,11 в опытных до 1,15 ммоль/л - в контрольной группах соответственно. Содержание кальция и фосфора в крови гусей опытных групп было ниже, чем в контроле, на 0,16-0,55 и 0,04-0,09 ммоль/л соответственно, что, на наш взгляд, связано с тем, что гусыни опытных групп обладали более высокой яйценоскостью, в связи с чем на образование яйца расходовалось больше минеральных компонентов по сравнению с особями контрольной группы.

Таким образом, исходя из результатов анализа морфобиохимического состава крови гусынь на пике продуктивности, можно сделать вывод, что наиболее высокий уровень содержания гемоглобина и форменных элементов, 
цветного показателя и резервной щелочности было обнаружено у гусей при фазовом кормлении, что свидетельствует о лучшем насыщении крови кислородом, а также более интенсивном обмене веществ в организме птицы. При этом наилучшие показатели были выявлены в крови гусынь опытной-3 группы, в рационе которых содержание обменной энергии и сырого протеина составляло: в первой фазе продуктивности - 270 ккал и 17\%, во второй фазе - 275 ккал и 17,5\%, в третьей фазе - 270 ккал и 17\% соответственно. Меньшее содержание кальция и неорганического фосфора в сыворотке крови гусей опытных групп, на наш взгляд, объясняется тем, что при более высокой яйценоскости расходуется больше минеральных компонентов на образование яйца, а относительно низкий уровень остаточного азота свидетельствует о меньшем накоплении продуктов распада в организме птицы при фазовом кормлении.

Снижение расхода и повышение эффективности использования кормов оказывает влияние на производственно-экономические показатели предприятия. При фазовом кормлении у гусей отмечались более высокие затраты корма в расчете на 1 голову в сутки и в среднем за период продуктивности колебались в пределах 329,02-335,5 г/гол. в сутки. В контроле данный показатель составил 327,42 г и был ниже на 0,52,5 \% по сравнению с опытными группами. Однако, в расчете на 10 шт. яиц наименьшие затраты корма были выявлены у гусей опытной-3 группы и составили в среднем за продуктивный период 12,5 кг, что было ниже на 4,8-10,7\%, чем в других группах. Это, на наш взгляд, связано с более высокой яйценоскостью гусынь опытной-3 группы по сравнению с другими группами.

На основе результатов исследований нами была проведена производственная проверка и рассчитана экономическая эффективность применения фазового кормления гусей в зависимости от уровня продуктивности. В качестве базового варианта послужило родительское стадо гусей итальянской породы, кормление которых производилось по традиционной схеме, согласно методическим рекомендациям ВНИТИП, а в новом варианте - родительское стадо гусей итальянской породы с содержанием обменной энергии в рационе в первой фазе яйцекладки 270 ккал., во второй - 275 и в третьей -270 ккал и сырого протеина на уровне 17,0; 17,5 и 17,0\% соответственно.

Исходя из результатов производственной проверки, выявлено, что сохранность гусей родительского стада в новом варианте составила
94,8 \% и на 4,1\% превышала показатель базового. Яйценоскость птицы в новом варианте увеличилась на 8,9 \%, по сравнению с базовым, а процент вывода гусят и кондиционного молодняка повысился на 4,2 и 22,4\% соответственно. Прибыль за счет реализации суточных гусят в новом варианте составила 404,2 тыс. руб., что на 149,7 тыс. руб. больше по сравнению с базовым вариантом, а уровень рентабельности производства возрос на 10,6\%, составив 36,7 \%.

\section{Выводы}

В продуктивный период гусей родительского стада целесообразно проводить фазовое кормление с учетом физиологического состояния и уровня продуктивности птицы с содержанием в рационе обменной энергии в первой фазе яйцекладки 270 ккал, во второй - 275 и в третьей 270 ккал и сырого протеина на уровне 17,0; 17,5 и 17,0\% соответственно, что позволяет повысить уровень рентабельности производства на 10,6\%.

\section{Библиографический список}

1. Мясное птицеводство в регионах России: современное состояние и перспективы инновационного развития / В.И. Фисинин, В.С. Буяров, А.В. Буяров, В.Г. Шуметов // Аграрная наука. -2018. №2. - С. 30-38.

2. Гусеводство России. Практическое руководство / Р.Р. Гадиев, А.Р. Фаррахов, В.Г. Цой, Н.С. Ковацкий. - Уфа: Белая река, 2016. - 223 с.

3. Гадиев, Р.Р. Венгерская технология разведения гусей: учебное пособие /Р.Р.Гадиев, В.Г. Цой. - Уфа: Башкирский ГАУ, 2014. - 102 с.

4. Гадиев, Р.Р. Гусеводство: учебное пособие (под грифом МСХ РФ) / Р.Р. Гадиев, В.Г. Цой, Н.С. Ковацкий. - Уфа: Башкирский ГАУ, 2015. - 296 с.

5. Суханова, С.Ф. Научное и практическое обоснование эффективности использования кормовых средств в гусеводстве / С.Ф. Суханова, Г.С. Азаубаева. - Курган: Изд-во Курганская ГСХА, 2015. $-472 \mathrm{c}$.

6. Гадиев, Р.Р. Продуктивные и воспроизводительные качества гусей при использовании хлореллы / Р.Р. Гадиев, Ч.Р. Галина, С.Р. Мажитов // Известия Оренбургского ГАУ. - 2015.-№3(53).-С.150153.

7. Гадиев, Р.Р. Хлорелла в рационах гусят /Р.Р. Гадиев, Д.Д. Хазиев //Современные проблемы науки и образования. - 2013. - № 5. - С. 685.

8. Галина, Ч.Р. Повышение качества ремонтного молодняка гусей /Ч.Р.Галина //Вестник Алтайского государственного аграрного университета. - 2013. - №3. - С.75-78.

9. Гадиев, Р.Р. Эффективность использова- 
ния сорго в рационах цыплят-бройлеров /Р.Р. Гадиев, А.Б. Чарыев // Известия Оренбургского государственного аграрного университета. - 2013. - № 6 (44). - С. 134-136.

10. Хазиев, Д.Д. Эффективность применения гуминовых веществ при выращивании гусят на мясо / Д.Д. Хазиев, Р.Р. Гадиев //Известия Оренбургского государственного аграрного универси- тета. - 2013. - № 6 (44). - С.141-144.

11. Фаррахов, А.Р. Инновационные методы в гусеводстве / А.Р.Фаррахов, Р.Р.Гадиев, Ч.Р. Галина //Птицеводство. 2015. - № 2. - С. 14-19.

12. Гематология сельскохозяйственной птицы /С.Ф.Суханова, Г.С. Азаубаева, А.П. Кузнецов, А.Г. Махалов. - Курган: Изд-во Курганская ГСХА, 2017. -404 c.

\title{
PHASE FEEDING IN GOOSE BREEDING
}

\author{
Galina Ch. R. \\ Bashkir Research Institute of Agriculture is a separate structural subdivision of the Federal State Budget \\ Scientific Institution of Ufa Federal Research Center of the Russian Academy of Sciences. \\ 450059, Republic of Bashkortostan, Ufa, Richard Sorge st., 19. \\ Mob. tel .: + 7-937-16-44-516; e-mail: chulpan-galina@mail.ru
}

Key words: geese; feeding; exchange energy; protein; productivity; hematological parameters; economic efficiency.

The aim of the research was to increase the productive qualities of geese of the parent flock by phase feeding, depending on physiological state and productivity level. The research was carried out on Italian breed geese of the parent flock in the goose breeding enterprise of OOO Bashkirskaya Ptitsa of Blagovarsky District of the Republic of Bashkortostan. A control group and three experimental groups of 20 heads each were formed. The geese of the test groups were fed by phase depending on the level of productivity. As for the ration of the first test group, the content of exchange energy in the first productivity phase was $260 \mathrm{kcal}$, in the second - 265, in the third - $270 \mathrm{kcal}$ with the content of crude protein - 16.0; 17.0 and $17.5 \%$, respectively. As for the second test group, the content of exchange energy was 270; $275 ; 270 \mathrm{kcal}$, and crude protein - 16,5; 17.0 and 16.5\%, respectively; in the third test group - $270 ; 275$ and $270 \mathrm{kcal}$ of exchange energy and 17.0; 17.5\% and 17.0\% of crude protein, respectively. The geese of the control group had ordinary ration according to the recommendations of All-Russian Research and Technology Institute of Poultry. According to the results of the research, live weight of the geese of the test group-3 was higher, on average, by $4.0 \%$ by the end of the productive period, egg production - by 10.3\%, egg weight by - 1.0\%, compared to the control. The blood of the geese of the experimental group 3 had a greater content of hemoglobin - by 6.9\%, erythrocytes by $3.83 \%$, and leukocytes by $6.5 \%$, as compared with the control. The hatching percentage of certified goslings in the test group-3 increased by $22.4 \%$, in comparison to the control, and the level of profitability increased by $10.6 \%$. Thus, during the productive period of the geese of the parent flock, it is reasonable to use phase feeding with $270 \mathrm{kcal}$ of exchange energy in the ration in the first phase, 275 in the second phase, $270 \mathrm{kcal}$ in the third and 17.0, 17.5\% and 17.0\%, of crude protein, respectively.

Bibliography

1. Meat poultry farming in the regions of Russia: the current state and prospects of innovation development / V.I. Fisinin, V.S. Buyarov, A.V. Buyarov, V.G. Shumetov // Agrarian Science. -2018. - №2. - P. 30-38.

2. Goose breeding of Russia. Practical guidance / R.R. Gadiev, A.R. Farrakhov, V.G. Tsoi, N.S. Kovatsky. - Ufa: Belaya Reka, 2016. - 223 p.

3. Gadiev, R.R. Hungarian technology for goose breeding: a study guide /R.R.Gadiev, V.G. Tsoi. - Ufa: Bashkir State Agrarian University, 2014 . - 102 p.

4. Gadiev, R.R. Goose breeding: textbook (under the signature of the Ministry of Agriculture of the RF)/ R.R. Gadiev, V.G. Tsoi, N.S. Kovatskiy. - Ufa: Bashkir State Agrarian University, 2015.-296 p.

5. Sukhanova, S.F. Scientific and practical substantiation of the effectiveness of feed usage in goose breeding / S.F. Sukhanova, G.S. Azaubaeva. - Kurgan: Kurgan State Agricultural Academy, 2015. - 472 p.

6. Gadiev, R.R. Productive and reproductive qualities of geese in case of chlorella application / R.R. Gadiev, Ch.R. Galina, S.R. Mazhitov // Izvestiya of Orenburg State Agrarian University. - 2015.-No.3 (53).-P.150-153.

7. Gadiev, R.R. Chlorella in rations of goslings / R.R. Gadiev, D.D. Khaziev // Current problems of science and education. - 2013. - No. 5. - P. 685.

8. Galina, Ch.R. Quality improvement of rearing flocks of young geese / Ch.R. Galina // Vestnik of Altai State Agrarian University. - 2013. - No3. - P.75-78.

9. Gadiev, R.R. Efficiency of using sorghum in rations of broiler chickens / R.R. Gadiev, A.B. Charyev // Izvestiya of Orenburg State Agrarian University. 2013. - No. 6 (44). - P. 134-136.

10. Khaziev, D.D. Efficiency of application of humic substances in breeding of goslings for meat / D.D. Khaziev, R.R. Gadiev // Izvestiya of Orenburg State Agrarian University. - 2013. - No. 6 (44). - P.141-144.

11. Farrakhov, A.R. Innovative methods in goose breeding / A.R. Farrakhov, R.R. Gadiev, Ch.R. Galina // Poultry breeding. 2015. - No. 2. - P. 14-19.

12. Hematology of agricultural poultry / S.F.Sukhanova, G.S. Azaubaeva, A.P. Kuznetsov, A.G. Makhalov. - Kurgan: Publishing house of Kurgan State Agricultural Academy, 2017. - $404 p$. 